\title{
Amino acids profile of rumen-undegradable protein of maize, rice bran, soyabean meal and rapeseed meal in steers*
}

\author{
C.Y. Xie ${ }^{1}$, H.J. Yang ${ }^{1,23}$, Q. Yue ${ }^{1}$, X.B. Yao ${ }^{1}$ and J.Q. Wang ${ }^{2}$ \\ ${ }^{1}$ Department of Animal Biology and Physiology, College of Biological Sciences, \\ China Agricultural University \\ Beijing 100094, P.R. China \\ ${ }^{2}$ State Key Laboratory of Animal Nutrition, Institute of Animal Science, \\ China Academy of Agricultural Sciences \\ Beijing 100094, P.R. China
}

\begin{abstract}
Maize, rice bran, soyabean meal and rapeseed meal were used to explore the effects of ruminal incubation on the amino acids profile of rumen-undegradable protein (RUP) in steers. Except maize, the disappearances of total amino acids (TAAs) and CP in feeds changed dramatically during former $24 \mathrm{~h}(\mathrm{P}<0.05)$, and some slight differences were found in the following $24 \mathrm{~h}(\mathrm{P}>0.05)$. Arginine and histidine were more sensitive to microbial degradation, but branch-chain AAs (isoleucine, leucine and phenylalanine) were more resistant. Microbial contamination should be taken into account to compare degradation rate of individual AA especially for branch-chain AAs in future research.
\end{abstract}

KEY WORDS: amino acid profile, in situ degradation, feed evaluation, ruminants

\section{INTRODUCTION}

In modern protein system, the values of effective degradable protein based on crude protein were normally used directly for prediction of amino acid protein degradability (Hvelplund and Weisbjerg, 2000). However, the decrease of proportion of TAA in CP after rumen incubation was found by Kowalczyk (1994), Harstad and Prestlùkken (2000) and Harazim et al. (2002), which indicated different degradability

\footnotetext{
* Supported by the Beijing Municipal Nature Science Foundation and National Nature Science Foundation of China

${ }^{3}$ Corresponding author: e-mail: yang_hongjian@cau.edu.cn
} 
of individual amino acid compared with those of crude protein in rumen undegradable protein (RUP) and original feedstuffs. In the case of individual AA, though Susmel et al. (1989) found it impossible to identify a general trend for individual AA in all feedstuffs, it was believed that there were some uniform patterns in particular AA by numerous studies. Since a few in situ incubation time points for assessment of amino acid reaching the intestine were adopted by most of laboratories, some significative details may not be discovered. The objective of this study is aimed to explore effect of in situ ruminal incubation on the amino acids profiles of RUP of maize, rice bran, soyabean meal and rapeseed meal commonly used in China.

\section{MATERIAL AND METHODS}

\section{Animals, feeding and chemical analysis of feeds}

Three steers (Simmental $\times$ Chinese local Yellow cattle crossbreed) were fitted with a permanent ruminal cannula (10 $\mathrm{cm}$ internal diameter), and with a T-type proximal duodenal cannula ( $2 \mathrm{~cm}$ internal diameter). They were housed in individual stall and clean water was always available for drink. The ration consist of $5 \mathrm{~kg}$ of Chinese wild rye $\left(896 \mathrm{~g} \mathrm{~kg}^{-1} \mathrm{DM}\right)$ and $5 \mathrm{~kg}$ of a commercial concentrate $\left(145 \mathrm{~g} \mathrm{~kg}^{-1}\right.$ crude protein), which was offered two equal meals a day at 08.00 and 20.00. The tested maize (MZ), rice bran (RB), soyabean meal (SBM) and rapeseed meal (RSM) were collected from commercial feed plants. The determination of DM, ash, EE and CP was followed by AOAC (1999). NDF and ADF were determined as described by Van Soest et al. (1991). The amino acid profiles were estimated by a HPLC system after the samples were hydrolysed in $6 \mathrm{M}$ hydrochloric acid for $24 \mathrm{~h}$ at $115^{\circ} \mathrm{C}$.

\section{In situ degradation}

The in situ incubation was applied according to de Boer et al. (1987). The rumenundegradable residues collected at $6,12,16,24$ and $36 \mathrm{~h}$ of in situ procedure were dried in a forced air oven at $60^{\circ} \mathrm{C}$ for $48 \mathrm{~h}$, equilibrated with room temperature and then weighed. Replicates within steers were pooled and ground through a $1 \mathrm{~mm}$ screen prior to $\mathrm{CP}$ and AA profile analysis.

\section{Statistical analysis}

The General Liner Models (GLM) procedure in SAS (1999) was used to analyse the effects of ruminal incubation on the disappearance of amino acids in RUP, with Duncan's multiple range test used for the comparison of means. The significance levels were 0.05 unless stated otherwise. 


\section{RESULTS AND DISCUSSION}

Chemical analysis of tested feeds was listed in Table 1. As shown in Table 2, the ruminal disappearance of $\mathrm{CP}$ was higher than that of TAA after $6 \mathrm{~h}$ in situ incubation. However, thereafter TAA accelerated their degradation so rapidly that the ruminal disappearance of theirs exceeded that of CP in SBM, RSM and RB.

Table 1. Chemical analysis of feeds, $\mathrm{g} \mathrm{kg}^{-1} \mathrm{DM}$

\begin{tabular}{lccccc}
\hline Feeds & CP & NDF & ADF & EE & Ash \\
\hline Maize (MZ) & 103.4 & 163.7 & 6.0 & 33.4 & 16.5 \\
Rice bran (RB) & 128.9 & 387.6 & 166.6 & 147.5 & 112.7 \\
Soyabean meal (SBM) & 497.5 & 153.8 & 96.1 & 17.3 & 73.9 \\
Rapeseed meal (RSM) & 409.5 & 375.7 & 260.1 & 18.3 & 110.3 \\
\hline
\end{tabular}

Table 2. The disappearance (\%) of total amino acids (TAA) and crude protein (CP)

\begin{tabular}{|c|c|c|c|c|c|c|c|c|}
\hline \multirow{2}{*}{ Feeds } & & \multicolumn{6}{|c|}{ In situ incubation time, $\mathrm{h}$} & \multirow{2}{*}{ SEM } \\
\hline & & 0 & 6 & 12 & 24 & 36 & 48 & \\
\hline \multirow[t]{2}{*}{$\overline{\mathrm{RSM}}$} & TAA & $10.52^{\mathrm{e}}$ & $28.33^{\mathrm{d}}$ & $45.73^{\mathrm{c}}$ & $63.74^{\mathrm{b}}$ & $83.38^{\mathrm{a}}$ & $88.33^{\mathrm{a}}$ & 2.32 \\
\hline & $\mathrm{CP}$ & $18.45^{\mathrm{e}}$ & $31.53^{\mathrm{d}}$ & $45.22^{\mathrm{c}}$ & $60.03^{\mathrm{b}}$ & $79.64^{\mathrm{a}}$ & $85.60^{\mathrm{a}}$ & 2.04 \\
\hline \multirow[t]{2}{*}{ SBM } & TAA & $5.49^{\mathrm{d}}$ & $27.78^{\mathrm{c}}$ & $57.13^{\mathrm{b}}$ & $86.20^{\mathrm{a}}$ & $94.17^{\mathrm{a}}$ & $98.41^{\mathrm{a}}$ & 4.06 \\
\hline & $\mathrm{CP}$ & $13.71^{\mathrm{e}}$ & $34.85^{\mathrm{d}}$ & $55.79^{c}$ & $84.55^{\mathrm{b}}$ & $96.15^{\mathrm{a}}$ & $97.23^{\mathrm{a}}$ & 2.45 \\
\hline \multirow[t]{2}{*}{$\mathrm{MZ}$} & TAA & $7.65^{\mathrm{b}}$ & $20.36^{\mathrm{b}}$ & $30.62^{\mathrm{ab}}$ & $34.04^{\mathrm{ab}}$ & $42.20^{\mathrm{ab}}$ & $61.57^{\mathrm{a}}$ & 9.65 \\
\hline & $\mathrm{CP}$ & $23.53^{\mathrm{b}}$ & $23.58^{\mathrm{b}}$ & $29.20^{\mathrm{b}}$ & $38.03^{\mathrm{b}}$ & $65.35^{\mathrm{a}}$ & $78.10^{\mathrm{a}}$ & 4.92 \\
\hline \multirow[t]{2}{*}{$\mathrm{RB}$} & TAA & $50.09^{d}$ & $56.84^{\mathrm{c}}$ & $67.75^{b}$ & $83.44^{\mathrm{a}}$ & $84.21^{\mathrm{a}}$ & $85.46^{\mathrm{a}}$ & 1.28 \\
\hline & $\mathrm{CP}$ & $52.08^{c}$ & $51.99^{\mathrm{c}}$ & $65.40^{\mathrm{b}}$ & $81.32^{\mathrm{a}}$ & $82.36^{\mathrm{a}}$ & $83.06^{\mathrm{a}}$ & 0.84 \\
\hline
\end{tabular}

a,b,c,d,e means within a row with the same letter are not significantly different $(\mathrm{P}>0.05)$ SEM - standard error of least square mean

These results were in agreement with Weisbjerg et al. (1996), as in their work water solubility of TAA was lower than $\mathrm{N}$ solubility for 14 different concentrate ingredients. Similar results were reported by Harstad and Prestlùkken (2000) in which the disappearance of TAA in feeds was higher than that of CP except that of SBM at $0 \mathrm{~h}$. Except for MZ, the disappearances of TAA and CP of others changed dramatically during former $24 \mathrm{~h}(\mathrm{P}<0.05)$, but in which only small difference were found in the following $24 \mathrm{~h}(\mathrm{P}>0.05)$, which showed in situ incubation time dependent.

There were at least two possible explanations for its degradation pattern: 1. rumen microorganism might prefer utilizing amino acid nitrogen (AAN) to no-AAN, 2. exposure of protein associated with fibre followed by digestion of the fibrous fraction might bring the drop to the degradability of TAA and CP.

Amino acids profile of RUP of different feeds were listed and compared in Table 3. It was concluded that individual AA in feeds were not degraded equally by the rumen microbes. Arginine and histidine from $\mathrm{MZ}$ were more sensitive 
Table 3. The essential amino acids (EAA) composition ( $\left(00 \mathrm{~g}^{-1} \mathrm{AA}\right)$ in original feeds (OF) and its rumen-undegraded protein (RUP)

\begin{tabular}{|c|c|c|c|c|c|c|c|c|}
\hline \multirow{2}{*}{$\begin{array}{l}\text { Amino } \\
\text { acid }\end{array}$} & \multirow{2}{*}{ Feeds } & \multicolumn{7}{|c|}{ In situ incubation time, $\mathrm{h}$} \\
\hline & & OF & 0 & 6 & 12 & 24 & 36 & 48 \\
\hline \multirow[t]{4}{*}{ Arg } & $\mathrm{MZ}$ & 4.83 & 4.36 & 3.87 & 2.81 & 3.22 & 3.40 & 3.34 \\
\hline & $\mathrm{RB}$ & 8.39 & 7.19 & 6.83 & 6.34 & 5.27 & 5.28 & 4.81 \\
\hline & SBM & 7.88 & 7.38 & 7.22 & 6.67 & 5.82 & 5.98 & 5.48 \\
\hline & RSM & 6.85 & 6.62 & 6.38 & 6.3 & 6.46 & 5.42 & 5.35 \\
\hline \multirow[t]{4}{*}{ His } & $\mathrm{MZ}$ & 2.95 & 2.85 & 2.76 & 2.49 & 2.29 & 2.07 & 2.30 \\
\hline & $\mathrm{RB}$ & 2.80 & 2.37 & 2.20 & 2.02 & 1.67 & 1.82 & 1.76 \\
\hline & SBM & 2.75 & 2.71 & 2.52 & 2.5 & 2.39 & 2.52 & 2.55 \\
\hline & RSM & 3.07 & 2.95 & 2.97 & 2.92 & 3.05 & 2.98 & 3.03 \\
\hline \multirow[t]{4}{*}{ Ile } & $\mathrm{MZ}$ & 3.61 & 3.63 & 4.16 & 4.40 & 4.46 & 4.22 & 4.25 \\
\hline & $\mathrm{RB}$ & 7.90 & 4.42 & 4.86 & 4.98 & 5.08 & 5.16 & 5.3 \\
\hline & SBM & 4.83 & 4.84 & 5.09 & 5.24 & 5.61 & 5.54 & 5.04 \\
\hline & RSM & 4.51 & 4.55 & 5.01 & 5.07 & 5.21 & 5.18 & 5.16 \\
\hline \multirow[t]{4}{*}{ Leu } & $\mathrm{MZ}$ & 12.43 & 13.01 & 13.91 & 14.25 & 13.9 & 13.69 & 14.28 \\
\hline & $\mathrm{RB}$ & 4.19 & 9.15 & 9.07 & 9.23 & 9.45 & 9.52 & 9.65 \\
\hline & SBM & 7.72 & 7.88 & 8.27 & 8.32 & 8.82 & 8.75 & 7.72 \\
\hline & RSM & 7.69 & 7.76 & 8.28 & 8.36 & 8.71 & 8.52 & 8.48 \\
\hline \multirow[t]{4}{*}{ Lys } & $\mathrm{MZ}$ & 2.74 & 2.16 & 2.38 & 2.35 & 2.83 & 2.84 & 2.56 \\
\hline & $\mathrm{RB}$ & 5.45 & 4.27 & 4.16 & 4.38 & 4.91 & 5.01 & 5.13 \\
\hline & SBM & 6.16 & 6.30 & 5.24 & 5.70 & 6.01 & 5.68 & 6.15 \\
\hline & RSM & 4.89 & 4.91 & 4.34 & 4.57 & 4.29 & 4.09 & 4.01 \\
\hline \multirow[t]{4}{*}{ Phe } & $\mathrm{MZ}$ & 5.19 & 5.34 & 5.71 & 5.85 & 5.8 & 5.57 & 6.05 \\
\hline & $\mathrm{RB}$ & 4.91 & 5.81 & 6.16 & 6.46 & 6.87 & 6.86 & 6.98 \\
\hline & SBM & 5.32 & 5.22 & 5.24 & 5.26 & 5.45 & 5.45 & 4.86 \\
\hline & RSM & 4.55 & 4.45 & 4.84 & 4.95 & 5.35 & 5.06 & 5.07 \\
\hline \multirow[t]{4}{*}{ Thr } & $\mathrm{MZ}$ & 3.37 & 4.48 & 3.58 & 3.1 & 3.19 & 3.43 & 3.26 \\
\hline & $\mathrm{RB}$ & 4.26 & 4.05 & 4.36 & 4.43 & 4.56 & 4.75 & 4.15 \\
\hline & SBM & 4.00 & 3.35 & 4.83 & 4.92 & 4.66 & 5.23 & 4.73 \\
\hline & RSM & 4.55 & 4.27 & 3.96 & 4.17 & 4.42 & 4.32 & 4.37 \\
\hline \multirow[t]{4}{*}{ Tyr } & $\mathrm{MZ}$ & 3.8 & 3.65 & 4.05 & 4.23 & 4.35 & 3.90 & 4.37 \\
\hline & $\mathrm{RB}$ & 3.28 & 3.28 & 3.33 & 3.09 & 2.56 & 2.62 & 2.72 \\
\hline & SBM & 4.10 & 3.64 & 3.97 & 4.10 & 4.16 & 4.25 & 4.01 \\
\hline & RSM & 3.33 & 3.19 & 3.52 & 3.48 & 3.47 & 2.76 & 2.63 \\
\hline \multirow[t]{4}{*}{ Val } & $\mathrm{MZ}$ & 4.80 & 4.84 & 5.08 & 5.08 & 4.9 & 4.74 & 4.79 \\
\hline & $\mathrm{RB}$ & 6.09 & 6.44 & 6.87 & 6.97 & 7.15 & 7.13 & 7.25 \\
\hline & SBM & 4.93 & 4.92 & 5.41 & 5.55 & 5.93 & 5.97 & 5.66 \\
\hline & RSM & 5.68 & 5.80 & 6.28 & 6.31 & 6.47 & 6.55 & 6.57 \\
\hline
\end{tabular}


to microbial degradation than the others, but isoleucine, leucine, tyrosine and phenylalanine were more resistant to be degraded than other feeds. The proportion of lysine in TAAs decreased rapidly after washing at $0 \mathrm{~h}$, but increased gradually in the rumen incubation. For RB, arginine and histidine consistently lowered its concentration along with prolonged ruminal exposure, but leucine, phenylalanine and valine were opposite. Degradation of isoleucine and lysine in RB progressed similarly to that of lysine in MZ. In SBM, continuously decreased for its proportion of arginine, on the contrary, isoleucine, leucine, tyrosine and valine increased in succession, but lysine content decreased firstly and increased later in the rumen. Higher degradation was shown for RSM in arginine and lower degradation was shown in isoleucine, leucine, tyrosine, valine and phenylalanine.

As mentioned above, changes in their AA profiles were feed dependent, but some common trends were observed. In agreement with majority of publications, arginine was one of more relatively degradable amino acid and its portion decreased with the passing of time in all feedstuff we tested. Erasmus et al. (1994) and Maiga et al. (1996) reported that histidine showed significantly higher ruminal degradation in protein feeds but the same was only found in cereal feed in present study. In the case of SBM, Harstad and Prestlùkken (2000) observed some slight variations of the proportion of histidine, which were consistent with the present results. The fact that phenylalanine, isoleucine and leucine seemed to be rather resistant to microbial degradation also had been accepted by above laboratories. All of results were also partially validated by the experiments of amino acid infusion (Kowalczyk, 1994), in which tyrosine and phenylalanine were also most resistant to decomposition in rumen, however, the group leucine and isoleucine were belong to was opposite to ours.

It would be notable that some irregular changes were found in some AA in our studies. For example, lysine had been considered as one of the more degradable AA by numbers of studies with one or two specific incubation timepoint, but in our study the increase of content taken place in former $24 \mathrm{~h}$, and Harstad and Prestlùkken (2000) published the similar results in SBM. Since Korhonen et al. (2002) had found rich of lysine and leucine in the AA profile of rumen particleassociated bacteria (PAB) and poor in arginine and histidine, caution must be taken to make the conclusions in description of AAs degradation in rumen.

\section{CONCLUSIONS}

Changes in AA profiles of RUP were feed and time dependent. AAs followed the common degradable pattern in the rumen, but microbial contamination should be taken into account to compare degradation rate of individual AA especially for lysine, leucine, arginine and histidine. 


\section{REFERENCES}

AOAC, 1999. Association of Official Analytical Chemists, Official Methods of Analysis. 16th Edition. Washington, DC

De Boer G., Murrhy J.J., Kennelly J.J., 1987. Mobile nylon bag for estimating intestinal availability of rumen undegradable protein. J. Dairy Sci. 70, 977-982

Erasmus L.J., Botha P.M., Cruywaen C.W., 1994. Amino acid profile and intestinal digestibility in dairy cows of rumen-undegradable protein from various feedstuffs. J. Dairy Sci. 77, 541-551

Harazim J., Třináctý J., Homolka P., 2002. Degradability and intestinal digestibility of crude protein and amino acids of extracted rapeseed meal. Czech J. Anim. Sci. 47, 50-56

Harstad O.M., Prestlùkken E., 2000. Effective rumen degradability and intestinal indigestibility of individual amino acids in solvent-extracted soybean meal (SBM) and xylose-treated SBM (SoyPass) determined in situ. Anim. Feed Sci. Tech. 83, 31-47

Hvelplund T., Weisbjerg M.R., 2000. In situ techniques for the estimation of protein degradability and postrumen availability. In: Forage Evaluation in Ruminant. CAB International, pp. 233258

Korhonen M., Ahvenjarvi S., Vanhatalo A., Huhtanen P., 2002. Supplementing barley or rapeseed meal to dairy cows fed grass-red clover silage: II. Amino acid profile of microbial fractions. J. Anim. Sci. 80, 2188-2196

Kowalczyk J., 1994. The rate of free amino acid disappearance from the rumen content in sheep. J. Anim. Feed Sci. 3, 11-22

Maiga H.A., Schingoethe D.J., Henson J.E., 1996. Ruminal degradation, amino acid composition, and intestinal digestibility of the residual components of five protein supplements. J. Dairy Sci. $79,1647-1653$

SAS, 1999. User's Guide: Statistics. Version 8.2. SAS Institute Inc. Cary, NC

Susmel P., Stefanon B., Mills C.R., Candido M., 1989. Change in amino acid composition of different protein source after rumen incubation. Anim. Prod. 49, 375-383

Van Soest P.J., Robertson J.B., Lewis B.A., 1991. Methods for dietary fiber, neutral fiber, and nonstarch polysaccharides in relation to animal nutrition. J. Dairy Sci. 74, 3583-3597

Weisbjerg M.R., Hvelplund T., Hellberg S., Olsson S., Sanne S., 1996. Effective rumen degradability and intestinal digestibility of individual amino acids in different concentrates determined in situ. Anim. Feed Sci. Tech. 62, 179-188 